\title{
Prospecções: doutores indígenas e a autoria acadêmica indígena no Brasil contemporâneo
}

\author{
Prospections: indigenous doctors and an first nations \\ academic authorship in contemporary Brazil
}

Inês Caroline Reichert ${ }^{1}$

DOI: http://dx.doi.org/10.20435/tellus.v0i0.550

\begin{abstract}
Resumo: O trabalho discute a Autoria Acadêmica Indígena no Brasil Contemporâneo a partir da qual indígenas têm se tornado Doutores, interrogando-me sobre os sentidos que essa autoria assume contemporaneamente. Situando o fenômeno social estudado nos contornos das Sociedades Complexas Urbano-Industriais, o qual abrange fluxos intensos de trocas culturais em diversas esferas éticas, parti do pressuposto de que a Autoria Acadêmica Indígena conforma uma paisagem, pelas teias de significados que vai tramando.
\end{abstract}

Palavras-chave: Autoria acadêmica indígena; doutores indígenas; paisagem.

Abstract: This Thesis discusses the First Nations Academic Authorship in the Contemporary Brazil as from which first nations people have become Doctors, questioning me about the meanings that this authorship assumes contemporaneously. Situating the social phenomenon studied in the countours of the Complex Urban-Industrial Societies, which encompases intense flows of cultural exchanges in several ethical espheres, I assumed that the First Nations Academic Authorship conforms a landscape, through the webs of meanings that it plots.

Keywords: First nations academic authorship; indigenous doctors; landscape.

\section{UMA CENA: PARA APRESENTAR AS QUESTÕES INVESTIGADAS}

Para introduzir a temática discutida neste artigo, narro brevemente uma cena acadêmica bastante familiar para aqueles que circulam no espaço acadêmico de pós-graduação brasileiro. Em 20 de dezembro de 2014, no Programa de PósGraduação em Linguística da Universidade de Brasília (UnB), ocorreu a defesa da tese de Doutorado "Para uma gramática da Língua HãxtaKuin". Porém, em lugar

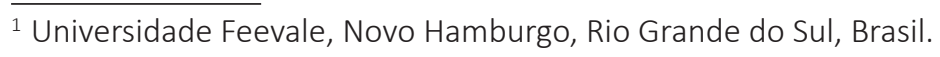


de constituir-se como um acontecimento ordinário e cotidiano nesse meio, tal sessão acadêmica representa um cenário inaugural no Brasil contemporâneo, qual seja, a formação de uma intelectualidade indígena constituída por indígenas que concluíram o Doutorado. Joaquim Paulo de Lima Maná Kaxinawá, autor da tese, foi o primeiro indígena acreano a se tornar Doutor e em sua trajetória social, foi seringueiro, peão, professor indígena, militante do Movimento Indígena, acadêmico de Ciências Sociais, pesquisador de sua cultura e, então, estudante de Pós-graduação.

Nessa cena, a Autoria Acadêmica Indígena retratada é compreendida por mim como um fenômeno social em emergência, pois, desde aproximadamente a década dos anos 2000, muitos indígenas, homens e mulheres, iniciaram percursos acadêmicos que os tornaram Doutores, compondo um grupo que no Brasil somava, em 2017, cerca de 24 pessoas, estando muitos outros ainda em formação na época. No contexto dos processos históricos de escolarização indígena que permitiram a chegada de indígenas aos cursos de pós-graduação, considero que cabe que se coloquem questões acerca dos sentidos que essa autoria vem assumindo. Assim, desde um ineditismo que "saltou" aos meus olhos, perguntei-me sobre os significados que a Autoria Acadêmica Indígena conforma nos diferentes espaços sociais por onde reverbera e circula, principalmente a partir das percepções que os Doutores Indígenas e seus povos têm sobre sua autoria.

Sobre o recorte nos Doutores Indígenas em si, isto é, naqueles indígenas que defenderam a tese e obtiveram o título acadêmico, aproximando-me da conceituação de campo científico de Bourdieu (2004, p. 25), busquei sublinhar a compreensão de que, no espaço acadêmico, operam códigos culturais que ampliam ou restringem o acesso e a mobilidade aos recursos e posições disponíveis, distribuindo, dessa forma, poder e hierarquia na estrutura do campo. Ao colocar meu ponto de clivagem nos indígenas com título de Doutores, focalizo as estratégias e as forças colocadas em jogo no campo intelectual acadêmico, por aqueles sujeitos que, no momento em que a pesquisa foi realizada, lograram conquistar um capital simbólico relevante a esse campo, o título de Doutor (BOURDIEU, 2004), cumprindo os ritos incluídos, como o momento da defesa da tese.

Parti de alguns pressupostos, como o entendimento de que à Autoria Acadêmica Indígena estão implicados processos de afirmação étnica, os quais 
busco identificar e discutir, localizando-os no complexo quadro das lutas dos povos indígenas pela garantia e efetivação de seus direitos contemporaneamente. A investigação se posiciona no campo da Antropologia Urbana que tem se denominado de Sociedades Complexas Urbano-Industriais, por compreender que a presença de grupos indígenas em contextos urbanos legitima essa abordagem, pautada nas dinâmicas culturais que se estabelecem nos contextos sociais e culturais gerados pela modernidade urbano-industrial, abrangendo, na noção de complexidade, a questão de uma heterogeneidade cultural, em que coexiste uma pluralidade de tradições de diversas bases (VELHO, 2003, p. 14).

Para tanto, no escopo deste artigo e no intuito de perseguir as tramas configuradas pelos sentidos que pretendo analisar, intentei delimitar a paisagem que a Autoria Acadêmica Indígena vem conformando, em um esforço que se apresenta com características prospectivas.

\section{PROSPECÇÕES: PARA DELIMITAR UMA PAISAGEM QUE SE CONFORMA}

Metodologicamente, utilizo-me de uma analogia que se pauta nas proximidades da pesquisa etnográfica com o campo da Arqueologia em meu objeto de análise. Tal opção parte de um pensar nas possibilidades de permanência do pensamento indígena em tramas outras, contemporâneas, como fenômenos de longa duração, nos interstícios de uma autoria que se inscreve em produções discursivas reguladas social e culturalmente, como o são as teses acadêmicas. Entendendo que a Arqueologia e a Etnografia trabalham em níveis analíticos diferentes, relativos a escalas espaço-tempo variáveis (CORRÊA, 2013, p. 28), minha escolha em utilizar a metáfora arqueológica para falar da Autoria Acadêmica Indígena, em um percurso que nomeei de etnográfico-arqueológico, se fez no sentido de demarcar as perspectivas de diálogo conceitual, dando destaque para uma história indígena de longa duração.

Assim, apresento a delimitação do campo social estudado como uma etapa similar à prospecção arqueológica. A prospecção, no trabalho do arqueólogo, tanto pode ser uma etapa inicial, preliminar a da escavação, quanto se constituir em metodologia principal do estudo, de acordo com os objetivos colocados para cada pesquisa. Em qualquer um dos casos, a prospecção caracteriza-se como um estudo majoritariamente de superfície, não invasivo portanto, no qual o arqueó- 
logo percorre a área estudada, reunindo dados e informações que the possibilitem reconstituir a "lógica" de assentamento humano do sítio arqueológico, bem como a inserção do mesmo em um contexto cultural mais amplo² (CARVALHO, 2007, p. 62).

Essa compreensão se insere em uma perspectiva culturalista da Arqueologia, na qual as investigações arqueológicas se debruçam sobre os elementos ambientais e culturais e suas inter-relações, atendendo aos espaços territoriais amplos e identificando padrões de assentamentos, para além dos espaços demarcados como assentamentos, uma compreensão que Criado Boado $(1991$, p. 6) caracterizou como conceito culturalista de paisagem. A paisagem arqueológica assume, consoante essa concepção, o caráter de fenômeno social dentro de contextos históricos específicos e, como tal, transmite símbolos interpretáveis em meio à teia de significados em que está envolvida (FAGUNDES; PIUZANA, 2010, p. 207), abarcando os processos e fenômenos culturais de longa duração. Nesse sentido, tomo as prospecções que fiz e compõem este artigo, no sentido de delimitar e apresentar o campo social e o universo estudado, as quais possibilitaram dar visibilidade a uma paisagem, um campo de significações.

Os dados que permitiram delimitar o universo da pesquisa e realizar a etnografia dos Doutores Indígenas e de suas obras são oriundos de observação participante em eventos científico-acadêmicos sobre o tema e que contavam com a sua presença; da base de dados acadêmica proveniente da Plataforma Lattes; e dos textos das teses produzidas pelos Doutores, propriamente. A partir desse conjunto de dados, em seguida procurei realizar algumas análises, sociológicas e etnográficas, consideradas em uma perspectiva prospectiva.

\footnotetext{
${ }^{2}$ A reconstrução dos padrões ou modelos regionais se insere nos quadros teórico-metodológicos colocados pela New Archaeology e pela Arqueologia Espacial, a partir da década de 70, e especialmente pela Arqueologia da Paisagem, derivada da Espacial (CARVALHO, 2007, p. 58). A partir desses referenciais, as prospecções deixaram de ocupar um lugar secundário no campo da Arqueologia para se projetarem como ponto central do corpo metodológico de muitas pesquisas. CARVALHO, Pedro C. Cova da Beira: ocupação e exploração do território na época romana (2007, p. 62).
} 


\section{APRESENTANDO OS DOUTORES INDÍGENAS ENFOCADOS}

São vinte e quatro os Doutores Indígenas estudados neste trabalho, em um processo de obtenção do título iniciado após os anos 2000. Esclareço que a questão da ausência de uma base de dados para a localização dos Doutores Indígenas foi algo que precisei ter em conta quando do levantamento inicial, considerando a possibilidade de eu não ter acessado, de forma totalizante, o número de indígenas com título de Doutorado até o momento em que finalizei a investigação, segundo semestre de 2017. Apesar disso, entendo que a análise é representativa de um caminho empreendido pelos povos indígenas na direção de uma Autoria Acadêmica, e que, por tal representatividade, se pôde levantar questões sobre ele ${ }^{3}$.

Para apresentá-los, optei por organizar um quadro a partir da indicação do nome, data de nascimento, origem étnica, local de origem, área de conhecimento do Doutorado e instituição em que realizou o Doutorado, título da tese e ano da defesa. Uma questão inicial que se depreende do número de pessoas identificado na pesquisa é a pequena representatividade dos indígenas no Doutorado, no que se relaciona ao conjunto da sociedade brasileira, isto é, proporcionalmente ao número de Doutores entre não indígenas. Isso se evidencia também nos dados do Censo 2010 do Instituto Brasileiro de Geografia e Estatística (IBGE), analisados por Viotti et al. (2012, p. 379), de que os indígenas representam 0,12\% do total de Doutores do País.

Quanto às etnias e comunidades de origem, foram inseridas de acordo com as referências feitas pelos Doutores Indígenas nas fontes pesquisadas. Optei por localizar essas comunidades regionalmente no território brasileiro, de maneira a possibilitar uma visão inicial das diversidades étnicas e também históricas dos processos de colonização a que foram submetidos os diferentes povos indígenas. Em seguida, cito a área de conhecimento e a Universidade em que a tese se vinculou, evidenciando, assim, as áreas prioritárias com as quais a Autoria Acadêmica Indígena dialoga e destacando, igualmente, um panorama das instituições que

\footnotetext{
${ }^{3}$ Assim, se por ventura algum indígena não foi contemplado no quadro que apresento para o período focalizado pela pesquisa, informo que isso se deve à dificuldade de acessar os dados, e não por qualquer categoria prévia de seleção. Entretanto desejo que aquele que não foi contemplado, sinta-se também representado neste estudo.
} 
fizeram parte do processo dessa autoria. Por fim, cito os títulos das teses e o ano de defesa, para permitir uma visão ampla das temáticas elencadas nos objetos de pesquisa dos Doutores Indígenas e dos aspectos relacionados à historicidade da produção acadêmica analisada.

Quadro 1-Doutores indígenas e suas teses

\begin{tabular}{|c|c|c|c|}
\hline NOME & ETNIA/TERRITÓRIO & $\begin{array}{c}\text { ÁREA DE } \\
\text { CONHECIMENTO }\end{array}$ & TESE/ANO \\
\hline $\begin{array}{c}\text { Almires Martins } \\
\text { Machado } \\
\text { 06/09/1967 }\end{array}$ & $\begin{array}{l}\text { Guarani/Terena } \\
\text { Aldeia Jaguapiru } \\
\text { e Bororó, na } \\
\text { região da Grande } \\
\text { Dourados, MS }\end{array}$ & $\begin{array}{l}\text { Doutor em } \\
\text { Antropologia, } \\
\text { Universidade } \\
\text { Federal do Pará } \\
\text { (UFPA) }\end{array}$ & $\begin{array}{l}\text { “Exá raú mboguatá } \\
\text { guassú mohekauka } \\
\text { yvy marãe'y: } \\
\text { de Sonhos ao } \\
\text { Oguatá Guassú } \\
\text { em Busca da(s) } \\
\text { Terra(s) Isenta(s) } \\
\text { de Mal", } \\
2015\end{array}$ \\
\hline $\begin{array}{c}\text { Ailton Alves Lacerda } \\
\text { Krenak } \\
\text { Ailton Krenak } \\
1954\end{array}$ & $\begin{array}{l}\text { Krenak } \\
\text { Itabirinha do } \\
\text { Mantena, região do } \\
\text { Vale do Rio Doce, } \\
\text { MG }\end{array}$ & $\begin{array}{l}\text { Doutor Honoris } \\
\text { Causa em } \\
\text { Botânica, } \\
\text { Universidade } \\
\text { Federal de Juiz de } \\
\text { Fora (UFJF) }\end{array}$ & 2016 \\
\hline
\end{tabular}




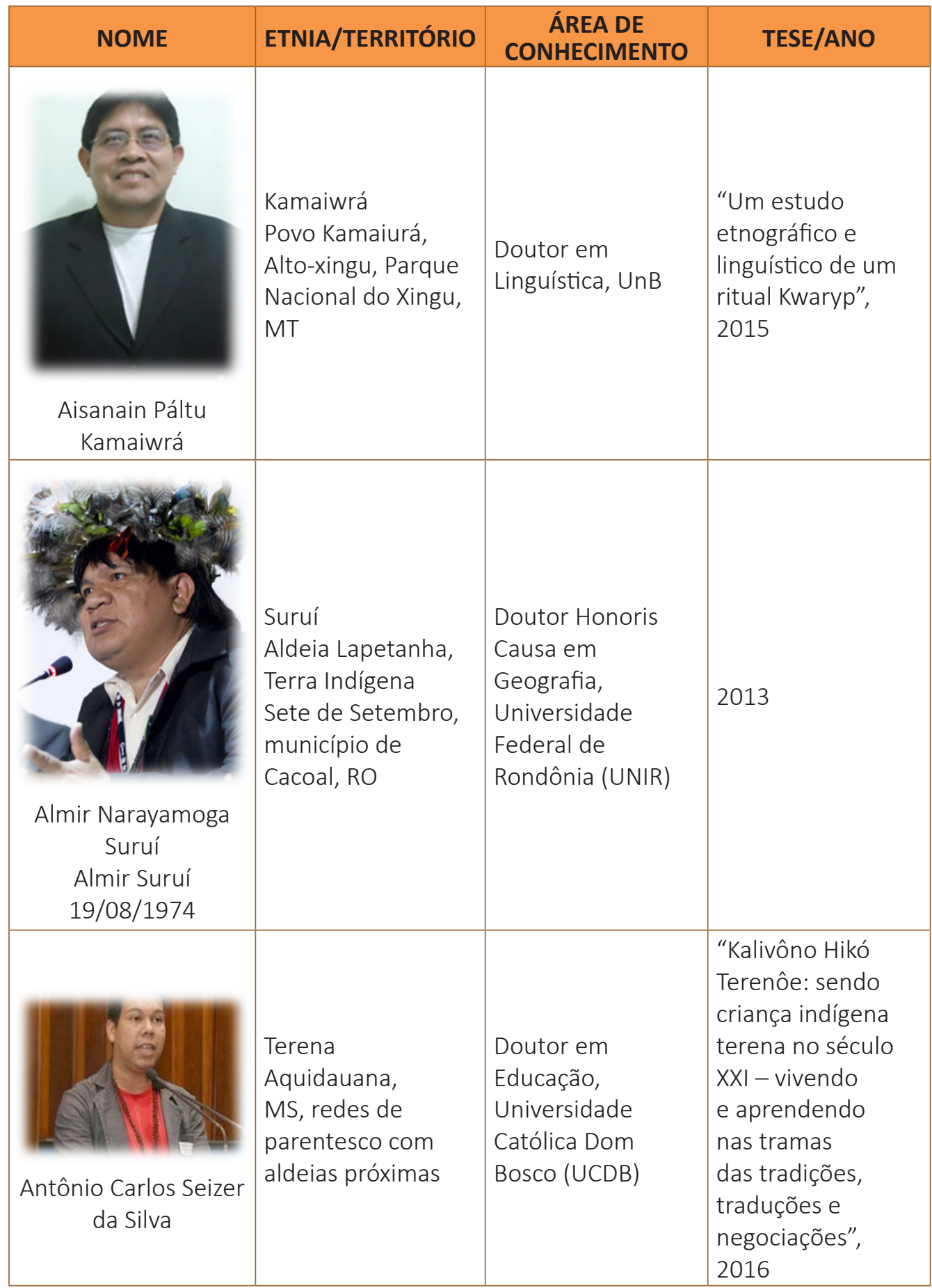




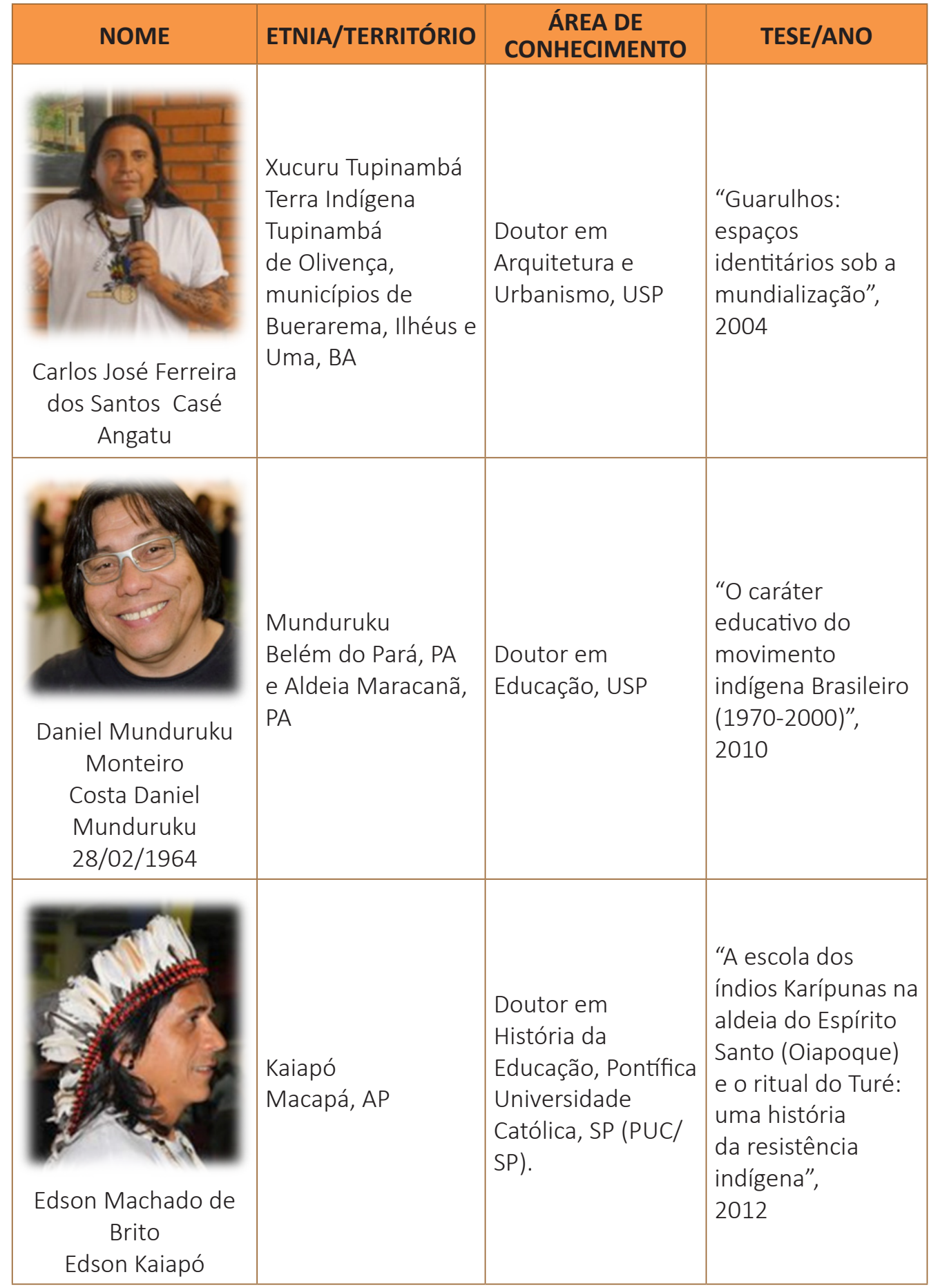




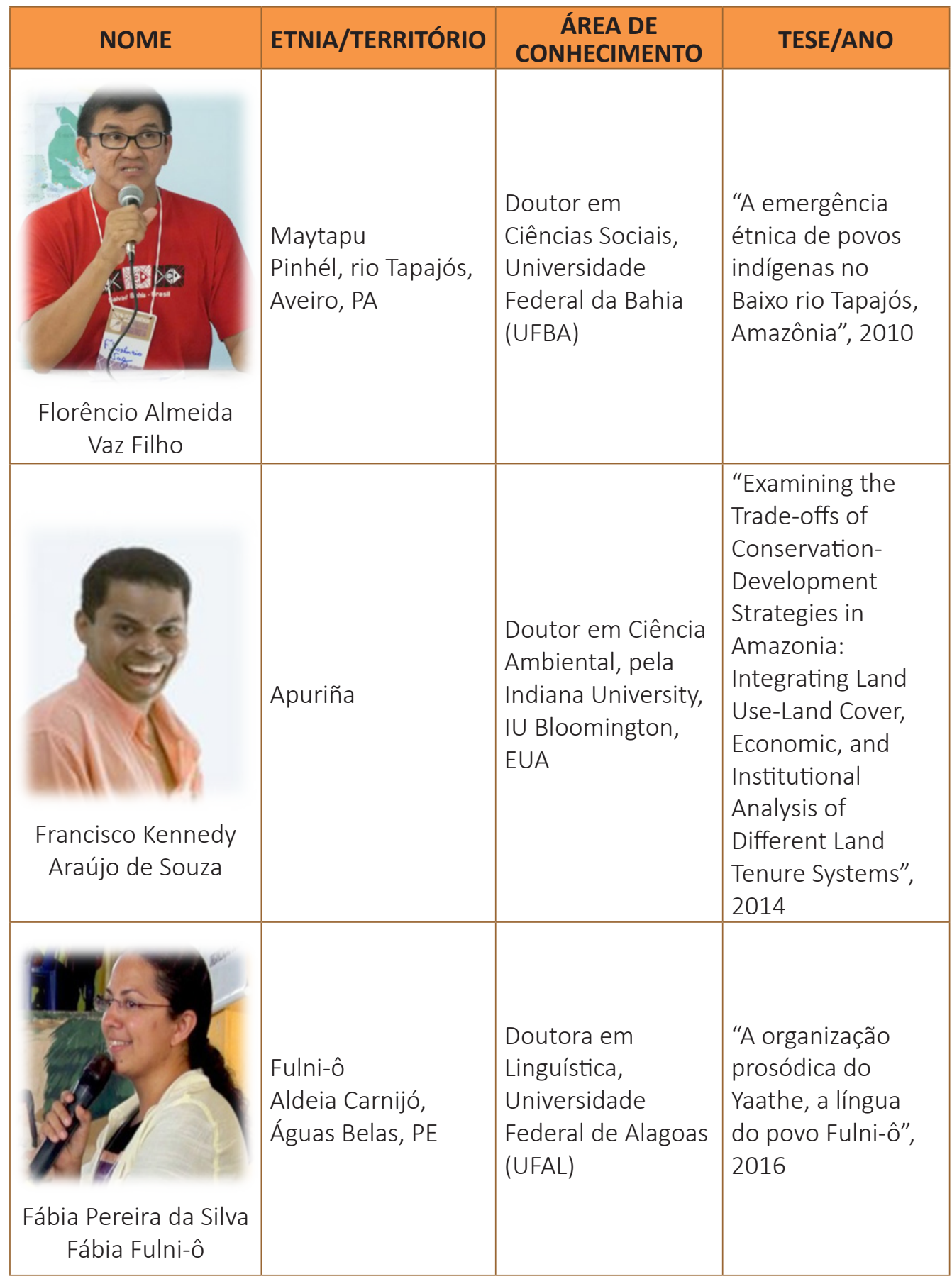




\begin{tabular}{|c|c|c|c|}
\hline NOME & ETNIA/TERRITÓRIO & $\begin{array}{c}\text { ÁREA DE } \\
\text { CONHECIMENTO }\end{array}$ & TESE/ANO \\
\hline $\begin{array}{l}\text { Gersem José dos } \\
\text { Santos } \\
\text { Luciano Gersem } \\
\text { Baniwa } \\
1964\end{array}$ & $\begin{array}{l}\text { Baniwa } \\
\text { Sítio Jaquirana, } \\
\text { margens do Rio } \\
\text { Içana, município } \\
\text { de São Gabriel da } \\
\text { Cachoeira, AM }\end{array}$ & $\begin{array}{l}\text { Doutor em } \\
\text { Antropologia } \\
\text { Social, UnB }\end{array}$ & $\begin{array}{l}\text { “Educação } \\
\text { para Manejo e } \\
\text { Domesticação } \\
\text { do Mundo: Entre } \\
\text { a escola ideal } \\
\text { e a escola real. } \\
\text { Os dilemas da } \\
\text { educação escolar } \\
\text { indígena no Rio } \\
\text { Negro", } 2011\end{array}$ \\
\hline $\begin{array}{c}\text { Jefferson Fernandes } \\
\text { do Nascimento } \\
1964\end{array}$ & $\begin{array}{l}\text { Macuxi } \\
\text { Aldeia Sumuru, } \\
\text { hoje Terra Indígena } \\
\text { Raposa Serra do } \\
\text { Sol, RR }\end{array}$ & $\begin{array}{l}\text { Doutor em } \\
\text { Agronomia, } \\
\text { Universidade } \\
\text { Estadual de } \\
\text { Maringá (UEM). } \\
\text { Primeiro Reitor } \\
\text { Indígena no Brasil }\end{array}$ & $\begin{array}{l}\text { "Epidemiologia e } \\
\text { dano causado pela } \\
\text { ferrugem asiática } \\
\text { (Phakopsora } \\
\text { pachyrizi) da soja } \\
\text { (Glycine max)", } \\
2008\end{array}$ \\
\hline $\begin{array}{c}\text { Joaquim Paulo de } \\
\text { Lima } \\
\text { Kaxinawá } \\
1964\end{array}$ & $\begin{array}{l}\text { Kaxinawá } \\
\text { Aldeia Tarauacá, } \\
\text { Terra Indígena da } \\
\text { Praia do Carapanã, } \\
\text { AC }\end{array}$ & $\begin{array}{l}\text { Doutor em } \\
\text { Linguística, UnB }\end{array}$ & $\begin{array}{l}\text { "Por uma } \\
\text { gramática da } \\
\text { Língua HãxtaKuin", } \\
2014\end{array}$ \\
\hline
\end{tabular}




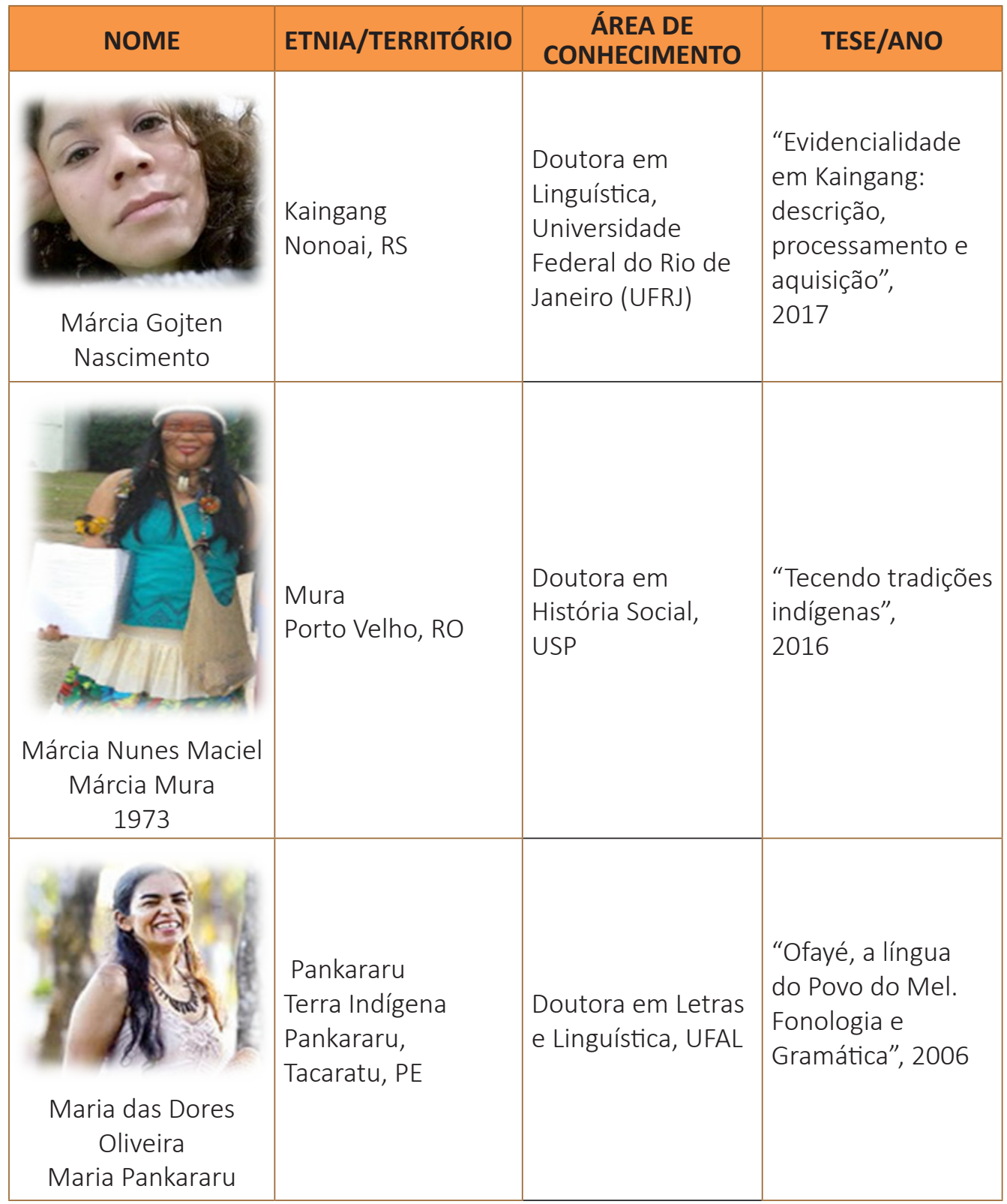




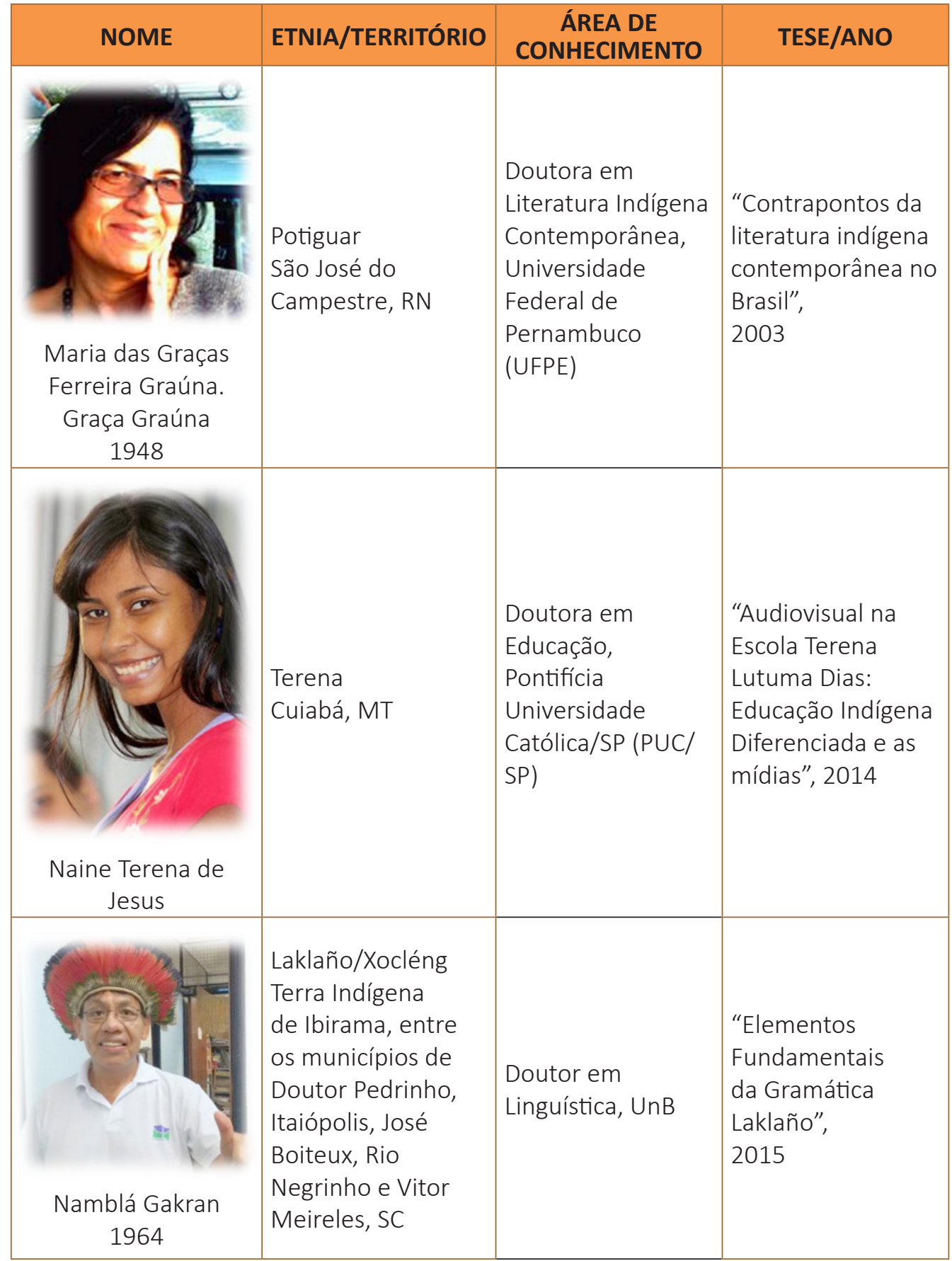




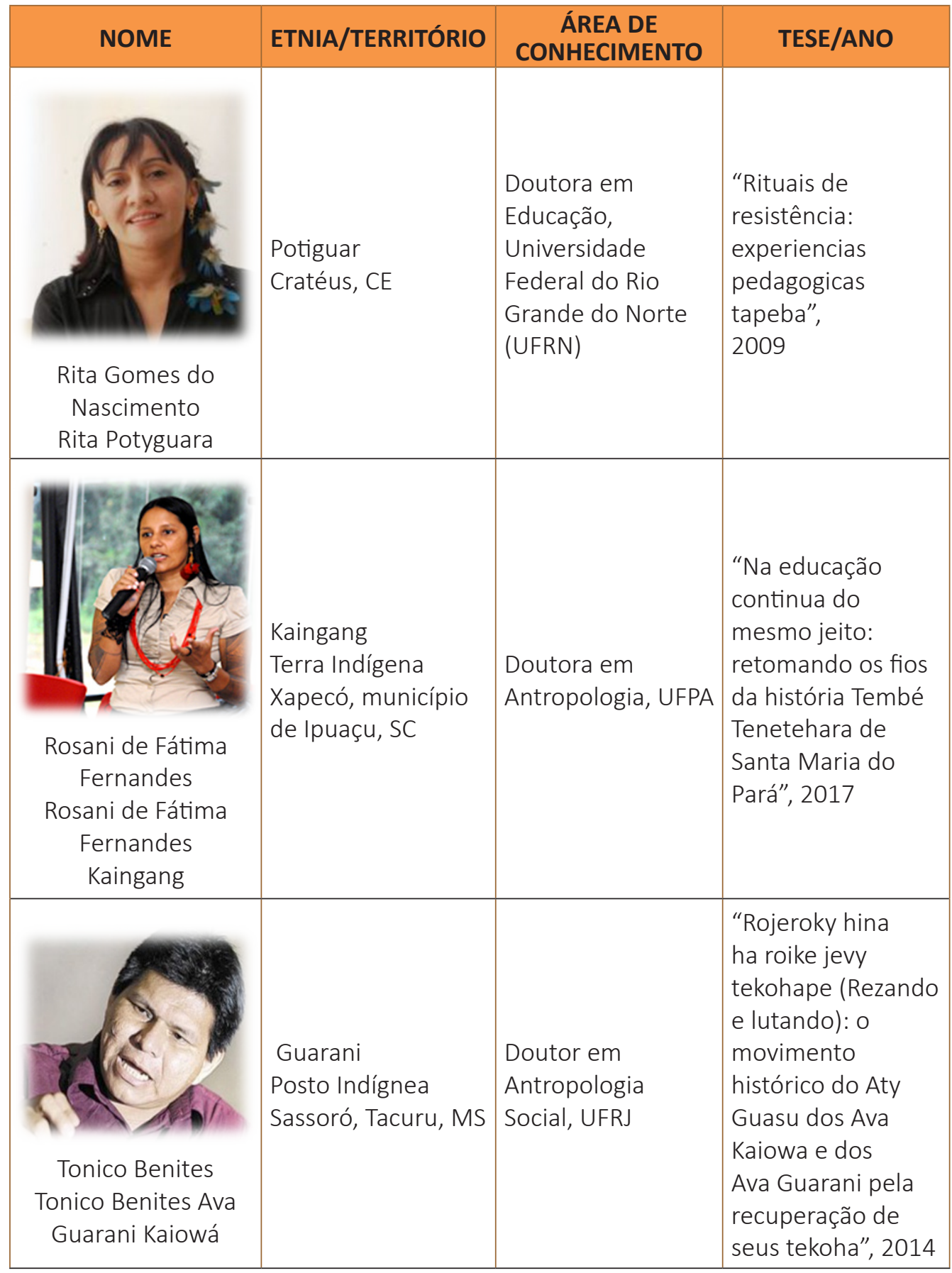




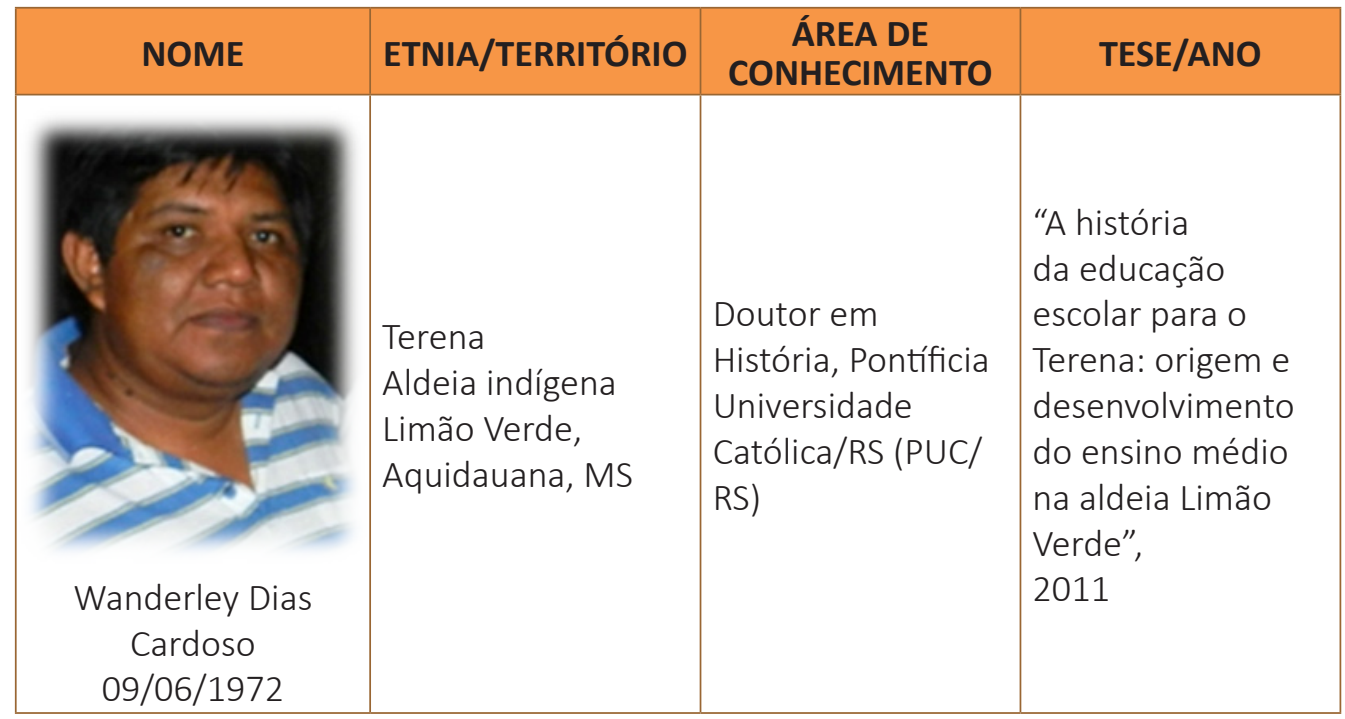

Fonte: Produção da autora, 2017.

\section{COLETAS DE SUPERFÍCIE: RECOLHENDO VESTÍGIOS}

Uma primeira visada nas informações do quadro demonstra o que se espera, de uma prospecção, que é dar visibilidade a determinados aspectos sobre a Autoria Acadêmica estudada. Inicio abordando a questão geracional e algumas convergências identificadas sobre essa temática. Conforme as datas de nascimento que pude levantar e as idades que estimei aproximadamente, agrupei os indivíduos em faixas etárias compreendidas por décadas. Assim, dos 24 Doutores, apenas dois possuem mais de 60 anos, Graça Graúna e Ailton Krenak. Na faixa etária de 50 anos ou mais, situei oito indivíduos, e na faixa etária dos 40 anos ou mais, encontram-se dez Doutores. Os mais jovens, na faixa etária de 30 anos ou mais, são em número de quatro. Em que pese a algumas possíveis variações nos números para cada faixa etária, é perceptível que parte do grupo era jovem no momento em que o país iniciava a abertura política pós-ditadura civil-militar, presenciando os acontecimentos dessa conjuntura histórica. Outra parte do grupo viveu e vive sua juventude nos cenários pró-indígenas mais contemporâneos, especialmente os gerados pelo protagonismo do movimento indígena e pela implementação de diversas ações afirmativas.

Para sublinhar essa questão, evoco uma cena da qual Ailton Krenak, um dos dois Doutores mais velhos, tomou parte ativamente, no sentido em que ela resume 
o cenário de lutas pela inclusão das pautas indígenas nos quadros da constituição de novos marcos jurídicos à época, e que concorreram para a conquista de políticas afirmativas, que são área de aderência deste trabalho por sua relação com a ampliação do acesso e da permanência de estudantes indígenas à escolarização, incluindo os níveis do Ensino Superior e do pós-graduação. Reconhecido militante do movimento indígena, junto com Mário Juruna ${ }^{4}$, entre outros líderes indígenas, Krenak teve intensa participação nos processos engendrados pela Assembleia Constituinte de 1987, de onde resultou a conquista de direitos históricos aos indígenas, promulgados na Constituição de 1988. Na época, com então 30 e poucos anos, Ailton proferiu um importante discurso, com o rosto pintado de tinta preta de jenipapo, evento que se tornaria um emblema para o movimento indígena e para os povos indígenas.

É possível imaginar que mais da metade do universo de minha pesquisa, aqueles que hoje estão na faixa de seus cinquenta anos e aqueles em torno de seus quarenta anos, tenha assistido a tais acontecimentos, e até mesmo participado, em pleno período de suas juventudes. Os mais jovens, que nasceram na década de 80 , realizaram seus itinerários de vida em campos sociais já marcados pela conquista constitucional de direitos aos povos indígenas. Portanto o grupo de Doutores Indígenas é constituído por indivíduos cujos percursos de vida se inserem em um tempo de direitos e lutas pela efetivação destes, capitaneados pelas organizações indígenas, tempo que possibilitou que emergisse uma liderança jovem e escolarizada. Denominadas entre os povos indígenas de lideranças políticas ou Novas Lideranças, segundo Luciano (2006, p. 65), esses líderes recebem tarefas específicas para atuar nas relações com a sociedade não indígena, ocupando funções importantes para a vida coletiva, o que acaba por modificar a configuração dos espaços de poder presentes nas culturas indígenas.

Bengoa (2000, p. 83) sinaliza essa emergência também em outros países da América Latina, sublinhando que a força política desse novo dirigente está em ser capaz de manejar os códigos ocidentais e, ao mesmo tempo, manejar a

\footnotetext{
${ }^{4}$ Mário Juruna foi um líder indígena, da etnia Xavante e tornou-se o primeiro indígena a eleger-se deputado federal no Brasil. Notabilizou-se, nos anos 70, por gravar as falas dos brancos quando dos processos de retomada de suas terras, empreendidos pelos Xavante (JURUNA; HOHFELDT; HOFFMANN, 1982; GRAHAM, 2011).
} 
distinção, o fato de ser indígena e pensar como indígena, o que confere sentido e legitimidade às suas reivindicações. A perspectiva apontada por Luciano (2006) e Bengoa (2000) é também enfatizada por Taiaiake Alfred (2016), Doutor em História e indígena da etnia Mohawk, em Quebec, Canadá, o que permite perceber contornos globais no fenômeno. Nesse sentido, cabe situar que o trânsito entre os códigos universais e a manutenção da distinção étnica, que passa a ser requerido para os novos dirigentes indígenas, insere-se como característica e possibilidade a partir da constituição de uma esfera macroética gerada pelas agências ligadas à Organização das Nações Unidas (ONU), uma macroesfera entendida como o espaço de onde emanam valores universalizáveis e que assumem uma dimensão de ética planetária (OLIVEIRA, 2004, p. 26).

Os Doutores Indígenas são, em sua maioria, homens. Dos vinte e quatro Doutores, há 16 homens e oito mulheres. No entanto, embora a participação das mulheres ainda seja menor em relação ao número total de Indígenas com titulação em nível de Doutorado, há aspectos a serem destacados sobre essa presença. Das cinco teses defendidas até 2010, três são de mulheres indígenas de etnias localizadas na região Nordeste do Brasil, indicando mais recentemente um expressivo protagonismo feminino no processo analisado. Embora a questão de gênero e representatividade das mulheres nos espaços da Ciência e nas Universidades guarde similaridades entre as mulheres em geral, isto é, indígenas e não indígenas, aqui tematizo a discussão a partir das especificidades das questões de gênero contemporaneamente nas culturas indígenas, campo de estudos em pesquisas desenvolvidas por Sachi e Gramkow (2012) e Zimmermann (2015).

A menor presença das mulheres indígenas entre os Doutores Indígenas e em pós-graduação, em geral, está ligada diretamente a uma menor presença de mulheres indígenas já na graduação e relaciona-se à questão cultural dos papéis de gênero entre povos indígenas (BERGAMASCHI; KURROSCHI, 2013, p. 10). Em muitas culturas, as mulheres são preparadas para serem mães ainda muito jovens, considerando-se os padrões não indígenas atuais em relação à maternidade, e, assim, quando completam a escolarização e tornam-se aptas para ingressar na graduação, muitas delas já são mães, enfrentando dificuldades em conciliar os estudos e o cuidado com os filhos. Para Rita Gomes do Nascimento, uma das Doutoras pesquisadas, a dificuldade em acessar a Universidade para as mulheres indígenas ocorre também pela dificuldade desta em lidar com a diversidade, em uma perspectiva intercul- 
tural, aceitando suas especificidades, posição derivada de um percurso histórico da Universidade em que a centralidade da erudição abstrata, o etnocentrismo e o racismo foram posturas dominantes (CATAFESTO DE SOUZA, 2013).

Apesar das dificuldades enfrentadas pelas mulheres indígenas, é importante registrar que, em termos de representatividade de gênero no conjunto de Doutores Indígenas, se evidencia um crescimento considerável na participação das mulheres indígenas, derivado das demandas de direitos reivindicados, desde 1980, em organizações brasileiras exclusivas de mulheres indígenas. Entre essas demandas, cabe ressaltar que se dirigem para a garantia dos territórios tradicionais, o direito à saúde e à educação diferenciada, buscando o fortalecimento de coletivo indígena (SACHI; GRAMKOW, 2012). Essa inserção das mulheres indígenas no mercado de trabalho e nos diversos níveis de escolarização é fruto das modificações nos papéis e nas relações de gênero nas comunidades, resultado de novos arranjos de organização familiar que compõem as mudanças advindas das relações entre os povos indígenas e o mundo não indígena, como discutem Sachi e Gramkow (2012, p. 16).

Os 24 Doutores abrangidos na pesquisa representam 18 etnias diferentes, de um conjunto de 305 etnias vivendo no Brasil, totalizando, segundo o Censo 2010 do IBGE, 896.917 pessoas, falantes de 274 idiomas. ${ }^{5}$ Meu olhar para as origens étnicas dos Doutores Indígenas, nesse exercício de prospecção, faz-se no sentido de que compreendo que são diversas as culturas agregadas sob a categoria "indígena", utilizada para denominar as sociedades que habitavam as Américas quando da chegada dos europeus. São também múltiplos seus processos de contato com o mundo branco e com o Colonialismo, diferenciando-se, assim, suas configurações contemporâneas. Concordando com Luciano (2006, p. 50) de que as dinâmicas sociais e a intensidade da relação com a identidade étnica variam de povo para povo e regionalmente, de acordo com o processo de contato vivido, parto do pressuposto de que a essas questões estão imbricados os processos de Autoria Acadêmica dos Doutores Indígenas. Portanto julgo pertinente ressaltar aqui, ainda que brevemente, como se distribuem, no território brasileiro, as etnias às quais se vinculam os Doutores Indígenas, destacando que, no contexto do que chamamos

\footnotetext{
${ }_{5}$ Portal Brasil. Disponível em: http://www.brasil.gov.br/governo/2012/08/brasil-tem-quase-900-mil-indios-de-305-etnias-e-274-idiomas. Acesso em: 1o dez. 2017.
} 
de Brasil, estão colocadas dimensões de território diferenciadas, a moderna e as ameríndias, em diálogo e tensão (FREITAS, 2008, p. 18).

Considerando essas prerrogativas e tensionamentos, opto por apresentar a distribuição das etnias representadas pelos Doutores Indígenas em quatro regiões que aglutinam processos semelhantes em relação ao contato entre povos indígenas e colonizadores europeus, mas que se diferenciam entre si. São elas: a Amazônia Legal, uma área proposta pelo governo brasileiro com base em um critério sociopolítico e não geográfico, considerando necessidades pautadas pela ótica desenvolvimentista, e que engloba a totalidade dos estados do Acre, Amapá, Amazonas, Mato Grosso, Pará, Rondônia, Roraima e Tocantins e parte do Estado do Maranhão; ; região Nordeste/Sudeste, que coincide com os estados da região brasileira denominada de Nordeste - excetuando parte do estado do Maranhão, abarcado na Amazônia Legal - e parte da região Sudeste, contemplando os estados de Minas Gerais, Espírito Santo e Rio de Janeiro7; a região Centro-Oeste, compreendendo os estados de Mato Grosso do Sul e Goiás, excetuando o estado do Mato Grosso, que também integra a Amazônia Legal; a região Sul/Sudeste, abrangendo inteiramente os estados que compõem a região sul e o estado de São Paulo8.

Assim, das 18 etnias representadas pelos 24 Doutores Indígenas focalizados na pesquisa, nove delas situam-se na região da Amazônia Legal, totalizando 11 Doutores: Munduruku, com dois indígenas; Kaiapó; Kamaiurá; Mura; Baniwa; Macuxi; Apurinã; Suruí; Kaxinawá e Terena, com um Doutor cada uma. Nessa área, localizam-se as terras indígenas mais extensas, que em parte coincidem

\footnotetext{
${ }^{6}$ A abrangência da Amazônia Legal, nesse sentido, não é definida pelo bioma Amazônia, sendo composta também pelo Cerrado e pelo Pantanal matogrossense e corresponde a $61 \%$ do território brasileiro. Nos nove estados residem 55,9\% da população indígena brasileira, cerca de 250 mil pessoas, segundo dados da FUNASA. Disponível em: O Eco. Disponível em: http://www. oeco.org.br/dicionario-ambiental/28783-o-que-e-a-amazonia-legal/. Acesso em: 10 nov. 2017.

7 Para a junção dos estados da região Sudeste, com exceção do estado de São Paulo, aos da região Nordeste, baseei-me na aproximação que o movimento indígena faz entre os processos identitários e demandas societárias que envolvem as etnias que vivem nessas regiões brasileiras, especialmente concretizada na organização da entidade Articulação dos Povos Indígenas do Nordeste, Minas Gerais e Espírito Santo (APOINME), em 1990. (LUCIANO, 2006, p. 22).

${ }^{8}$ Optei por manter o estado de São Paulo na categoria regional dos estados da região sul, compondo uma região sul/sudeste, de forma a respeitar os territórios tradicionais das etnias Kaingang e Guarani, que se estendem a partir daí para o sul do Brasil.
} 
com os territórios indígenas tradicionais, característica que não é uma realidade nas demais regiões do país. Estão na região também os grupos indígenas conhecidos como isolados, ou povos em situação de isolamento voluntário, termo que designa aqueles grupos que optaram pelo não contato sistemático com as culturas do entorno, e com os quais a FUNAI não estabeleceu contato ${ }^{9}$. É também relativo à Amazônia o estereótipo sobre os povos indígenas, bastante difundido e, de certa forma, ainda presente para a sociedade brasileira, de "serem esses os 'verdadeiros índios', porque falavam suas línguas, viviam nas selvas nus e pintados e praticavam danças exóticas estranhas às danças do mundo não indígena" (LUCIANO, 2006, p. 42).

No Centro-Oeste, situam-se quatro Doutores, dois Terena e dois Guarani, localizados em Mato Grosso do Sul. A região contava com ocupação humana há milênios, tanto o planalto quanto o pantanal, e, no período colonial, foi fortemente impactada pela expansão da fronteira desenvolvimentista do Estado brasileiro ${ }^{10}$. As fases do contato diferiram significativamente entre si, passando de relações de parceria em seu início - registradas entre os portugueses e os Guanás, como eram conhecidos os Terena - a relações violentas de expropriação e confinamento, a partir do período Imperial e, posteriormente, também com a atuação do Serviço de Proteção ao Índio (SPI) e com o avanço dos colonizadores brancos na região, já no século XX.

Na região Nordeste/Sudeste, há seis Doutores: um tupinambá; uma Fulni-ô; uma Pankararu, um Krenak e duas Potiguares. Além de contar com uma participação feminina majoritária, há que se sublinhar um pioneirismo das etnias indígenas localizadas no Nordeste no processo de Autoria Acadêmica Indígena, pois, das cinco teses defendidas antes de 2010, quatro situam-se aí, aspectos que busco relacionar, na tese, às especificidades que revestem as questões de identidade e território dos povos indígenas localizados no Nordeste brasileiro. Região de intensa ocupação pré-cabralina (MARTIN, 1997), foi o primeiro ponto da ocu-

\footnotetext{
9 Povos Indígenas no Brasil. Disponível em: https://pib.socioambiental.org/pt/c/no-brasil-atual/ quem-sao/Indios-isolados. Acesso em: 10 nov. 2017.

${ }^{10}$ A ocupação humana do Mato Grosso do Sul foi estudada e difundida principalmente pelo Programa Arqueológico do Mato Grosso do Sul (1985-2001), coordenado pelo arqueólogo Pe. Pedro Ignácio Schmitz, do qual se originaram diversas produções acadêmicas (EREMITES, 2012, p. 180).
} 
pação portuguesa e, por isso, palco de processos de intensa e antiga exposição ao Colonialismo, que contemporaneamente concorreram para a constituição de uma invisibilização dos povos indígenas, nessas regiões, pela sociedade envolvente e pelo Estado, que entendiam esses indígenas como remanescentes sem direitos étnicos, "caboclos" que em pouco se diferenciavam dos não indígenas (OLIVEIRA, 2013, p. 13; OLIVEIRA,1998, p. 53). A partir dos anos 70, porém, esses grupos, mobilizados por suas organizações e por ações indigenistas, reiniciaram a reafirmação e a recriação de suas identidades indígenas, em processos a que a Antropologia tem denominado de etnogêneses, tendo como elementos diacríticos balizadores das identidades indígenas, para as etnias no Nordeste brasileiro, as festas do Turé e o uso da Jurema (GRÜNEWALD, 2008, p. 44)11.

Nas regiões Sul/Sudeste estão três Doutores, duas Kaingang e um Xocleng/ Laklaño. A região conta com uma história de ocupação humana que remonta a pelo menos 10000 anos (KERN, 1991), em territórios que, para os grupos jê-meridionais, abarcavam desde a bacia do rio Tietê, ao norte, até o sistema Guaíba-Patos, ao sul. Em relação aos Guarani, estima-se que seus ancestrais tenham cruzado o Rio Uruguai, vindos do norte, há cerca de 2000 anos e que, no momento da chegada dos europeus, ocupavam extensa região litorânea, desde o sul de São Paulo até o Rio Grande do Sul, interiorizando-se a partir das bacias dos rios Paraná, Uruguai e Paraguai (FREITAS, 2008, p. 19). O Brasil meridional foi também fortemente impactado pelo Colonialismo, com ações que envolveram diferentes ciclos produtivos, a partir dos quais a expansão europeia ia se configurando nos limites políticos e territoriais que se estabeleceram desde então, no sul do Brasil.

O quadro dos Doutores Indígenas também permitiu visualizar as instituições envolvidas no processo de formação em nível de pós-graduação e a sua historicidade. Em relação a esse último aspecto, as cinco pioneiras teses foram defendidas entre 2003 e 2009. Os demais 19 Doutores finalizaram seus Doutorados entre 2010 até 2017, sendo que, destes, 13 defenderam a partir de 2014, um número que

\footnotetext{
${ }^{11}$ Embora não sejam registrados unicamente na região, os processos de etnogêneses aí se deram primeiramente e em maior número, sendo, o fenômeno, um aspecto emblemático no que se relaciona às demandas societárias, especialmente dos povos indígenas no Nordeste (ARRUTI, 2006, p. 51). O autor discute que foi no Nordeste brasileiro que ocorreu pela primeira vez a reivindicação de identidade indígena por grupos de caboclos, no que ele denomina de primeiro ciclo, entre os anos 20 a 40 do século XX. Esses movimentos de reivindicação étnica seriam retomados em um segundo ciclo, iniciado nos anos 70 (ARRUTI, 2006, p. 50-4).
} 
demonstra um crescimento significativo, fortemente associado à implementação de ações afirmativas no nível da pós-graduação. Para ilustrar esse aspecto, destaco as ações da Universidade Federal do Pará (UFPA), da Universidade de Brasília (UnB) e da Universidade Católica Dom Bosco (UCDB), que respondem conjuntamente pelo Doutorado de sete dos Doutores Indígenas, com base em ações afirmativas para ingresso no pós-graduação implementadas no período (OLIVEIRA, 2016; BELTRÃO; CUNHA, 2011, p. 11) 12. É importante sublinhar também que, além das instituições em si, em alguns casos, a atuação de pesquisadores em campos de estudos ligados às temáticas indígenas foi preponderante para a entrada dos então doutorandos indígenas em determinado Programa de Pós-Graduação (PPG) ${ }^{13}$.

Nesse cenário, o Programa Internacional de Bolsas para o Pós-Graduação da Fundação Ford ocupa posição central por seu pioneirismo. Constituiu-se como o primeiro programa de ação afirmativa para o pós-graduação brasileiro, tendo sido implementado no Brasil pela Fundação Carlos Chagas em conjuntura muito especial, que foi a do intenso debate sobre ações afirmativas na Universidade brasileira e da expansão da pós-graduação no país, mas que ainda atendia a um perfil de formação das elites nacionais. De 2002 a 2009, foram realizados oito processos seletivos com oferta de 40 vagas, com foco preferencial para candidatos negros e indígenas, oferecendo bolsas para Mestrado e Doutorado. Alguns dos primeiros Doutores do universo pesquisado foram bolsistas Ford, como Maria Pankararu, Gersem Baniwa, Namblá Gakran e Francisco Kennedy de Souza (ATHIAS; PINTO, 2008; p. 7; ROSEMBERG, 2013, p. 4).

Ao visualizar o quadro conformado pelo universo da pesquisa, é perceptível que emergem áreas de conhecimento relacionadas a alguns campos específicos, estratégicos aos povos indígenas, e que aqui foram aglutinados em dois níveis diferentes, um, a partir da inserção nos Programas de Pós-Graduação (PPG), e outro, a partir de categorias que emergiram da análise dos objetos focalizados nas teses. Olho separadamente para as áreas de conhecimento elencadas pela vinculação ao PPG e para o recorte de objeto dado em cada tese, porque compreendo que, embora guardem proximidades, o recorte dado no objeto investigado pelos

\footnotetext{
12 Para uma historicização mais ampla das instituições envolvidas, consultar Oliveira (2016).

${ }^{13}$ Cito como exemplo, para esse aspecto específico, a professora Ana Suelly Arruda Câmara Cabral, da UnB (CABRAL et al., 2013), dentre outros pesquisadores.
} 
Doutores indígenas é que permite demonstrar, de forma mais contundente, a relação entre a Autoria Acadêmica Indígena e os projetos e demandas societárias dos povos indígenas.

Contudo o acento ao recorte no objeto feito pelos Doutores não retira a importância da identificação dos PPGs nos quais se vinculam a produção das teses, pois trata-se de um indicador que permite evidenciar quais áreas estão mais abertas ao diálogo intercultural, isto é, quais áreas abriram suas portas primeiramente e com as quais os Doutores Indígenas tiveram que lidar em termos de epistemologias e referenciais teóricos para a construção de sua Autoria Acadêmica. Assim, considerando-se o PPG em que ocorreu o vínculo, para mapear essas áreas prioritárias e evidenciar algumas possibilidades de análise, utilizei a tabela empregada pela Coordenação de Aperfeiçoamento de Pessoal de Nível Superior (CAPES) para Áreas do Conhecimento, categorizando os PPGs dos Doutores Indígenas em dois níveis classificatórios, os maiores hierarquicamente, nomeados na tabela por Grandes Áreas e Áreas de Conhecimento ${ }^{14}$.

Os processos de Doutoramento realizaram-se majoritariamente em duas das Grandes Áreas elencadas pela tabela da CAPES, a) Ciências Humanas e b) Linguística, Letras e Artes, totalizando 20 teses, o que, em termos percentuais, significa 83,33\% do total de 24 Doutoramentos analisados. Na Grande Área de Ciências Humanas, concentra-se o maior número, com 13 teses, sendo quatro teses em Antropologia; quatro em Educação; duas em História; uma em História da Educação; uma em Ciências Sociais e uma em Geografia. Na segunda Grande Área com maior número, Linguística, Letras e Artes, situam-se sete Doutoramentos, sendo seis em Linguística e um em Literatura Indígena Contemporânea. As demais teses inserem-se em três outras Grandes Áreas, listadas com suas respectivas Áreas de Conhecimento nas quais se colocam as produções: Ciências Agrárias,

${ }^{14}$ Conforme a CAPES informa em seu site, a classificação das Áreas do Conhecimento tem finalidade prática, objetivando proporcionar às Instituições uma maneira funcional de sistematizar e prestar informações concernentes a projetos de pesquisa e recursos humanos. A organização das Áreas do Conhecimento na tabela apresenta uma hierarquização em quatro níveis, do mais geral ao mais específico, abrangendo nove grandes áreas nas quais se distribuem as 48 áreas de avaliação utilizadas pela CAPES. Estas áreas de avaliação, por sua vez, agrupam áreas básicas, ou áreas do conhecimento, subdivididas em subáreas e especialidades. Fonte: FUNDAÇÃO CAPES MINISTÉRIO DA EDUCAÇÃO. Tabela Áreas do Conhecimento/Avaliação. Disponível em: http://www.capes.gov.br/avaliacao/instrumentos-de-apoio/tabela-de-areas-do-conhecimento-avaliacao. Acesso em: 25 out. 2017. 
com duas teses, uma na Área de Conhecimento em Agronomia e outra tese em Recursos Florestais e Engenharia Florestal; Ciências Biológicas/Botânica; Ciências Sociais Aplicadas/Arquitetura, Urbanismo e Design.

Considerando-se as Grandes Áreas eleitas, pode-se depreender dos dados algumas questões relevantes, como uma incidência majoritária na entrada dos indígenas em PPGs das Ciências Humanas e em Linguística, Letras e Artes e uma participação pequena de indígenas em PPGs das áreas exatas e da saúde, registrando, do total de 24 Doutores analisados, dois apenas na área das Ciências Agrárias, e os dois Doutores Honoris Causa, em Botânica e Geografia. Mesmo na área das chamadas Ciências Sociais Aplicadas há pouca incidência, registrando-se uma tese na área da Arquitetura, Urbanismo e Design. Essa questão é reconhecida pelos povos indígenas, como ressalta Rita Nascimento (2017), que avalia que "a preferência se dá por serem as Ciências Humanas as áreas do conhecimento que lidam e refletem sobre a interculturalidade, um tema praticamente ausente do campo das Ciências Exatas". Ressalto também que em minha percepção, essas escolhas diferem em parte das que se observa serem as áreas preferenciais demandadas pelos povos indígenas para o Ensino Superior - a saber, Educação, Saúde, Direito e Ciências Ambientais - por considerar que o pós-graduação possui uma dimensão do saber científico e da produção de conhecimento voltadas para a questão da autoria acadêmica em si, e não diretamente relacionadas a uma profissionalização, como na graduação ${ }^{15}$.

Há que se destacar aqui um outro aspecto que emerge dos dados, pois, se forem considerados os agrupamentos por Áreas de Conhecimento, deslocam-se as posições analisadas pelo corte de Grande Área. Por Área de Conhecimento, colocam-se, em ordem decrescente pelo número de teses produzidas, Letras/ Linguística, com seis; Educação/História da Educação, com cinco; Antropologia, com quatro, História, com duas; as demais, com uma tese cada, ou seja, é a Linguística a área com maior número de produções, seguida pela Educação. Considero que - avançando a questão para além do aspecto citado anteriormente, de que essas áreas estão mais abertas na Universidade ao diálogo com

\footnotetext{
${ }^{15}$ Essas são as áreas mais demandadas no Ensino Superior, consideradas estratégicas para os povos indígenas. Se relacionam à conjuntura da Constituição de 1988, que gerou postos de trabalho nessas áreas para os povos indígenas, e às necessidades das lutas pela implementação de seus direitos (BERGAMASCHI; KURROSCHI, 2013, p. 5).
} 
a interculturalidade - essas incidências estão a demonstrar a relação intrínseca entre a Autoria Acadêmica Indígena e os processos de afirmação identitária e fortalecimento das culturas indígenas, nos quais as Línguas Indígenas e a escola ocupam lugares centrais e estratégicos.

A demanda pelo Doutoramento em Linguística reflete também um crescimento do campo acadêmico ligado ao estudo das Línguas Indígenas no país, no âmbito dos PPGs e na constituição de um corpo de intelectuais desse campo, aptos não somente a atuarem como orientadores, mas que também foram pioneiros em fomentar ações afirmativas para formação de linguistas nativos. Conforme Rodrigues (2005, p. 35), esse processo teve grande crescimento a partir de um programa especial, criado pelo Conselho Nacional de Desenvolvimento Científico e Tecnológico (CNPq), o Programa de Pesquisa Científica das Línguas Indígenas Brasileiras (PPCLIB), destinado a fomentar tanto a pesquisa como a formação de pesquisadores. Embora tenha sido encerrado nos anos seguintes, o Programa estimulou que outros Programas de Pós-Graduação investissem em linhas destinadas à Linguística e Línguas Indígenas, área então existente apenas na Universidade Estadual de Campinas (UNICAMP), e que mantivessem a área como prioridade. Nessa conjuntura, iniciaram-se trabalhos na Universidade Federal de Goiás (UFG), Universidade Federal de Pernambuco (UFPE), Universidade Federal do Rio de Janeiro (UFRJ), Universidade Federal de Santa Catarina (UFSC) e UnB.

Percebe-se a convergência da historicidade da área da Linguística para o Pós-Graduação com os dados advindos do quadro de instituições nas quais se desenvolvem as teses na área da Linguística, com destaque em especial para a UnB, que através da Experiência Piloto de Formação de Mestres e Doutores Indígenas em Linguística Teórica, Descritiva e Histórica no Brasil contribuiu para o Doutoramento de três dos Doutores Indígenas estudados, Aisanain Kamaiwrá, Joaquim Kaxinawá e Namblá Gakran (CABRAL et al., 2013, p. 158) ${ }^{16}$. Desde a perspectiva de retomada de territórios e fortalecimento e afirmação das culturas indígenas realizadas pelos povos indígenas contemporaneamente, a questão da revitalização das línguas, em processos que contem com protagonismo dos indígenas, é ponto central da agenda dos povos indígenas.

\footnotetext{
${ }^{16}$ A experiência esteve articulada à Rede de Estudos, Pesquisas e Formação de Professores Pesquisadores em Linguística e Educação Escolar Indígena, contemplada pelo Edital n. 001/2009, da CAPES/DEB (Diretoria de Educação Básica) (CABRAL et al., 2013, p. 157).
} 


\section{AUTORIA ACADÊMICA INDÍGENA: DAS DIMENSÕES DE UMA PAISAGEM QUE SE DESCORTINA}

Para finalizar minhas prospecções, volto minha atenção para o recorte elegido pelos Doutores Indígenas, no sentido em que entendo que, nos objetos estudados, se evidencia o que defendo neste artigo, de que a Autoria Acadêmica Indígena está imbricada aos processos de lutas e afirmações identitárias empreendidos pelos povos indígenas contemporaneamente. Aqui, anuncio o que, em um primeiro momento, se dá a ver nesse panorama. Com base na leitura dos títulos das teses, de seus resumos e dos esclarecimentos anunciados em suas introduções, construí categorias de maneira a agrupar objetos de estudo próximos. São seis as categorias que emergiram dessa análise, sendo que quatro estão diretamente relacionadas à temática indígena: Linguística/Letras; Educação Escolar Indígena; Cosmovisão e Culturas Indígenas; Movimentos Indígenas e Afirmações Identitárias; Ciências Agrárias; e Urbanização e Globalização.

A montagem desse conjunto de categorias, tal qual o caminhar no campo de uma etnógrafa-arqueóloga, permitiu-me depreender as teias de significados que compõem a tessitura da paisagem arqueológica (FAGUNDES; PIUZANA, 2010 , p. 207). Tomando esses significados como dimensões do campo, anuncio primeiramente a dimensão da estratégia, percebida na relação que se estabelece com as áreas do conhecimento consideradas prioritárias e para as quais os povos indígenas têm direcionado a produção da Autoria Acadêmica. Defendo que a escolha dessas áreas e das temáticas de pesquisa evidenciadas nos objetos estudados se dá a partir de questões fulcrais aos movimentos, lutas e organizações dos povos indígenas contemporaneamente, e que, portanto, compõem estratégias historicamente construídas, consoante a questão do protagonismo indígena que anunciei anteriormente. Essa percepção coincide em parte com o mapeamento que focalizou os PPGs e as Áreas de Conhecimento em que se inserem as teses, demonstrando a prioridade dada ao estudo das línguas indígenas e à educação escolar indígena. Foi também possível dar visibilidade para questões que pautam contemporaneamente a agenda dos povos indígenas, tais como o movimento indígena, os processos de afirmação identitária, a retomada das terras indígenas, a composição de uma autoria literária indígena e a apropriação de novas tecnologias. 
A segunda dimensão evidenciou-se quando analisei o "como" os objetos de estudo estão pensados pelos Doutores Indígenas em suas teses, denotando discussões que situam os campos estudados em diálogo com questões que advêm das mudanças trazidas pelo contato com o mundo branco. A escola, por exemplo, é discutida como um espaço tanto de tradição, quanto de resistência, como nas teses de Edson Kayapó e Rita Nascimento, que enfocam rituais de resistência nos espaços escolares. Ela, a escola, também é compreendida como local onde se aprende o trânsito entre dois mundos e, nesse sentido, é posta em exame na tese de Gersem Baniwa e na de Wanderley Cardoso, que analisa sua historicidade na comunidade de Limão Verde. Os modos de apropriação cultural e os efeitos que esse espaço da cultura não indígena, a educação escolar, tem produzido nas culturas indígenas, são discutidos por Rosani Fernandes e Naine Terena de Jesus.

Essa perspectiva também é evidenciada por Antônio da Silva, que em sua tese situa as tradições como implicadas em processos de tradução e negociação, bem como na tese de Márcia Mura, que, através da oralidade das culturas, vai "puxando" e percebendo a tessitura da tradição entre os povos amazônicos, em contextos contemporâneos. As tradições dos Guarani são estudadas por Almires Machado, na tese que aborda a caminhada histórica que esse povo continua a empreender atualmente. Nesse sentido, as produções dos Doutores Indígenas demonstram que as questões que os interpelam, advindas das relações que estabelecem com o Estado e com a sociedade não indígena, e para as quais eles buscam responder também a partir da Autoria Acadêmica, se encontram inseridas às dinâmicas culturais a que os povos indígenas estão implicados, nos contornos das Sociedades Complexas Urbano-Industriais das quais fazem parte (ROCHA; ECKERT, 2011, p. 112).

E a última dimensão dessa paisagem é a que visualizei quando cotejei os objetos estudados pelos Doutores com as suas origens étnicas ou com as origens étnicas de povos indígenas estudados pelos Doutores Indígenas. Foi possível perceber a relação que se estabelece entre a etnia enfocada, sua história de contato com o mundo branco, diversa para cada região, e os processos identitários empreendidos. Para ilustrar essa dimensão, cito os Doutores Indígenas, autores de cinco teses, que estudaram os povos indígenas situados no Nordeste e no Pará, tematizando a questão das etnogêneses de povos indígenas e de rituais de resis- 
tência, e, com isso, alinhando seus trabalhos a processos que aí se colocam com força. Alinhamento semelhante pôde ser percebido nas nove teses de autoria de Doutores Indígenas oriundos de etnias situadas na Amazônia, que destacam, em seus objetos de pesquisa, as especificidades das demandas culturais e de manejo dos territórios dos povos indígenas localizados na região amazônica.

A resistência e os processos de retomada dos Tekohá pelos Guarani em Mato Grosso do Sul são tema do antropólogo Tonico Benites, enquanto Naine de Jesus e Wanderley Cardoso analisam questões em torno da presença da escola em suas aldeias de origem. Ou seja, na academia, o olhar voltou-se para a aldeia, com forte acento para os linguistas, que estudam as línguas nativas pela perspectiva indígena. Sob esse ângulo, os objetos estudados pelos Doutores Indígenas denotam as demandas societárias que emanam das diferentes posições que ocupam os povos indígenas no território brasileiro, na relação que estabelecem com o Estado nacional e com a sociedade envolvente, e dos processos próprios de organização e luta. Essa dimensão abrange também as teses que discutem processos identitários inseridos em decorrência da construção de uma pan-indianidade, como as de Graça Graúna e Daniel Munduruku, que abordam movimentos e protagonismo indígena, como a organização do movimento indígena e a literatura, em cenários contemporâneos.

Para finalizar este texto que caracterizo como uma saída exploratória ao campo, olho para essas dimensões e para a paisagem que elas conformam conjuntamente, não como uma unidade empírica observável, mas como o resultado de uma composição dos significados simbólicos que pude depreender nessas prospecções (ROCHA; ECKERT, 2011, p. 112). E o que meu olhar alcança ver é que os objetos de estudo dos Doutores Indígenas, inseridos em um cenário possibilitado pelos movimentos indígenas e pela ética emanada em uma escala planetária e em reverberação com uma escala mesoética, nacional (OLIVEIRA, 2004), demonstram um alinhamento às demandas societárias dos povos indígenas. Tais demandas se inscrevem, a partir de suas cosmovisões e tradições, nas dinâmicas culturais que se estabelecem entre os povos indígenas e a sociedade não indígena, envolvendo uma pluralidade de círculos e redes sociais, conflitos, continuidades e descontinuidades culturais e diferenciações sociais, em tempos nos quais os povos indígenas são chamados a se pronunciarem sobre quem são (BENGOA, 2000, p. 13). A essa indagação, as Novas Lideranças constroem respostas 
diversas e plurais, sendo, uma delas, a constituição de uma Autoria Acadêmica, estrategicamente acionada em determinados campos do conhecimento.

Ainda, trago um princípio que fundamentou minha relação de pesquisa, que é o entendimento que a etno-grafia que dela resulta é uma interpretação minha, que faço como desdobramento da convivência, no tensionamento do texto etnográfico. Nesse sentido, assumo os riscos e coloco minha própria autoria acadêmica à disposição no que ela tem a contribuir para as lutas dos povos indígenas e para as reflexões em torno de diálogos epistemológicos mais interculturais e equitativos, adensando as discussões que os povos indígenas, e não indígenas, já têm produzido sobre os sentidos da Autoria Acadêmica Indígena. Assim, apresento esse texto revestindo-o de um sentido de retorno à generosidade dos povos indígenas, por seus movimentos na direção da interculturalidade.

\section{REFERÊNCIAS}

ARRUTI, José Mauricio. Etnogêneses indígenas. In: RICARDO, Beto; RICARDO, Fany (Org.). Povos indígenas no Brasil: 2001-2005. São Paulo: Instituto Socioambiental, 2006. p. 50-4.

ATHIAS, Renato; PINTO, Regina Pahin (Org.). Estudos indígenas: comparações, interpretações e políticas. São Paulo: Contexto, 2008. (Série Justiça e Desenvolvimento).

BELTRÃO, Jane; CUNHA, Mainá Jailson Sampaio. Resposta à diversidade: políticas afirmativas para povos tradicionais, a experiência da universidade Federal do Pará. Espaço Ameríndio, Porto Alegre, v. 5, n. 3, p. 10-38, jul./dez. 2011. Disponível em: http://seer. ufrgs.br/EspacoAmerindio/article/view/21822. Acesso em 20 nov. 2017.

BENGOA, José. La emergência indígena em America Latina. Santiago/Chile: Fondo de Cultural Econômica, 2000.

BERGAMASCHI, Maria Aparecida; KURROSCHI, Andreia Rosa da Silva. Estudantes indígenas no ensino superior: o programa de acesso e permanência na UFRGS. Políticas educativas, Porto Alegre, v. 6, n. 2, p. 1-20, 2013.

BOURDIEU, Pierre. Os usos sociais da ciência: por uma sociologia clínica do campo científico. São Paulo: Unesp, 2004.

CABRAL, Ana Suelly Arruda Câmara et al. O observatório da educação escolar indígena e a experiência piloto de formação de mestres e doutores indígenas em linguística teórica, 
descritiva e histórica no Brasil. Revista Teoria e Prática da Educação, v. 16, n. 2, p. 157-68, maio/ago. 2013.

CARVALHO, Pedro C. Cova da Beira: ocupação e exploração do território na época romana. Coimbra: Fundão Editorial, 2007.

CATAFESTO DE SOUZA, José Otávio. Perspectivas ameríndias integradas ao universo acadêmico: o lugar dos indígenas na transformação polifônica da estrutura de ensino superior no Brasil. In: BERGAMASCHI, Maria Aparecida; NABARRO, Edilson; BENITES, Andréa. Estudantes indígenas no ensino superior: uma abordagem a partir da experiência na UFRGS. Porto Alegre: Editora da UFRGS, 2013. p. 113-27.

CORREA, Ângelo Alves. Longue durée: história indígena e arqueologia. Ciência e Cultura, São Paulo, v. 65, n. 2, p. 26-9, jun. 2013. Disponível em: http://cienciaecultura.bvs.br/ scielo.php?script=sci_arttext\&pid=S0009-67252013000200011\&lng=en\&nrm=iso. Acesso em: 5 fev. 2018.

CRIADO BOADO, Felipe Construcción social del espacio y reconstrucción arqueológica del paisaje. Bolétín de antropología americana, v. 24, p. 5-29, 1991.

EREMITES DE OLIVEIRA, Jorge. A história indígena no Brasil e em Mato Grosso do Sul. Espaço Ameríndio, Porto Alegre, v. 6, n. 2, p. 178-218, jul./dez. 2012.

FAGUNDES, Marcelo; PIUZANA, Danielle. Estudo teórico sobre o uso conceito de paisagem em pesquisas arqueológica. Revista Latinoamericana de Ciencias Sociales, Niñez y Juventud. Manizales, v. 8. n. 1, jan./jun. 2010.

FREITAS, Ana Elisa de Castro. Territórios ameríndios: espaços de vida nativa no Brasil meridional. In: BERGAMASCHI, Maria Aparecida (Org.). Povos Indígenas \& Educação. Porto Alegre: Mediação, 2008.

GRAHAM, Laura. Citando Mário Juruna: imaginário linguístico e a transformação da voz indígena na imprensa brasileira. Maná, Rio de Janeiro, v. 17, n. 2, p. 271-312, 2011. Disponível em: http://www.scielo.br/pdf/mana/v17n2/a02v17n2.pdf. Acesso em: 4 nov. 2017.

GRÜNEWALD, Rodrigo de Azeredo. Toré e Jurema: emblemas indígenas no Nordeste do Brasil. Ciência e Cultura, São Paulo, v. 60, n. 4, out. 2008. Disponível em: http:// cienciaecultura.bvs.br/scielo.php?script=sci_arttext\&pid=S0009-67252008000400018. Acesso em: 21 ago. 2017. 
JURUNA, Mario; HOHFELDT, Antônio; HOFFMANN, Assis. O gravador do Juruna. Porto Alegre: Mercado Aberto, 1982.

KERN, Arno Alvarez (Org.). Arqueologia pré-histórica do Rio Grande do Sul. Porto Alegre: Mercado Aberto, 1991.

LUCIANO, Gersem José dos Santos. O índio brasileiro: o que você precisa saber sobre os povos indígenas no Brasil de hoje. Brasília: Ministério da Educação, Secretaria de Educação Continuada, Alfabetização e Diversidade; Laced/Museu Nacional, 2006.

MARTIN, Gabriela. Pré-história do Nordeste. 2. ed. Recife: Editora Universitária - UFPE, 1997. $440 \mathrm{p}$.

NASCIMENTO, Rita Gomes do. Roda de Conversa "Políticas Afirmativas e a produção de conhecimentos nos PPGs". Porto Alegre: FACED/UFRGS, 27 out. 2017. [Depoimento verbal].

OLIVEIRA, Amanda de. Ações afirmativas nos programas de pós-graduação: experiências, a nova portaria do MEC e seus desdobramentos. ANPED, Rio de Janeiro, 29 jul. 2016. Disponível em: http://www.anped.org.br/news/acoes-afirmativas-nos-programas-depos-graduacao-experiencias-nova-portaria-do-mec-e-seus. Acesso em: 20 nov. 2017.

OLIVEIRA, Kelly Emanuelly de. Diga ao povo que avance! Movimento indígena no Nordeste. Recife: Fundação Joaquim Nabuco/Editora Massangana, 2013.

OLIVEIRA, João Pacheco de. Uma etnologia dos "índios misturados"? Situação colonial, territorialização e fluxos culturais. Mana, Rio de Janeiro, v. 4, n. 1, p. 4777, abr. 1998. Disponível em: http://www.scielo.br/scielo.php?script=sci_arttext\&pid =S0104-93131998000100003. Acesso em: 22 nov. 2017.

OLIVEIRA, Roberto Cardoso de. O mal-estar da ética na antropologia prática. In: OLIVEN; Ruben George; MACIEL, Maria Eunice; ORO, Ari Pedro (Org.). Antropologia e ética: o debate atual no Brasil. Niterói: Eduff, 2004. p. 21-32.

ROCHA, Ana Luiza Carvalho da; ECKERT, Cornelia. Etnografia da duração nas cidades em suas consolidações temporais. Revista de Ciências Sociais Política \& Trabalho, n. 35, abr. 2011, p.107-26. Disponível em: http://periodicos.ufpb.br/index.php/politicaetrabalho/ article/view/12185. Acesso em: 2 dez. 2017.

RODRIGUES, Aryon Dall'Igna. Sobre as línguas indígenas e sua pesquisa no Brasil. Ciência \& Cultura, São Paulo, v. 57, n. 2, p. 35-8, jun. 2005. Disponível em: http://cienciaecultura. 
bvs.br/scielo.php?script=sci_arttext\&pid=s0009-67252005000200018\&lng=en\&nrm=i so. Acesso em: 27 nov. 2017.

ROSEMBERG, Fúlvia. Ação afirmativa na pós-graduação: o programa internacional de bolsa da Fundação Ford na Fundação Carlos Chagas. São Paulo: FCC/SEP, 2013. Disponível em: http://www.publicacoes.fcc.org.br/ojs/index.php/ textosfcc/article/ download/2454/2408. Acesso em: 14 out. 2016.

SACCHI, Ângela; GRAMKOW, Márcia Maria (Org.). Gênero e povos indígenas: coletânea de textos produzidos para o "Fazendo Gênero 9" e para a "27ạ Reunião Brasileira de Antropologia". Rio de Janeiro: Museu do índio/GIZ/FUNAI. 2012.

TAIAIAKE ALFRED, George. Indigenous literatures in the Americas by Taiaiake Alfred. International writers blog. Hay festival: Cartagena de Indias. Colômbia, fev. 2016. Disponível em: http://blog.hayfestival.org/index.php/2016/02/taiaiake-alfred/. Acesso em: 11 jun. 2016.

VELHO, Gilberto. Projeto e metamorfose: antropologia das sociedades complexas. 3. ed. Rio de Janeiro: Jorge Zahar Editores, 2003.

VIOTTI, Eduardo B.; DAHER, Sofia; Queiroz, André S.; CARRIJO, Tomáz B. Mestres, doutores e os brasileiros de todos os níveis educacionais: revelações do censo 2010. In: VIOTTI, Eduardo B; DAHER, Sofia; Queiroz, André S. Mestres 2012: estudo da demografia da base técnico-científica brasileira. Brasília, DF: Centro de gestão e estudos estratégicos, 2012. Disponível em: http://www.cgee.org.br/hotsites/mestres2012_downloads/tabelas_pdf/ mestres2012_cap4.pdf. Acesso em: 4 nov. 2017.

ZIMMERMANN, Tânia Regina; SERAGUZA, Lauriene; VIANA, Ana Evanir Alves. Relações de gênero e violência contra mulheres indígenas em Amambai-MS (2007-2013). Espaço Ameríndio. Porto Alegre, v. 9, n. 1, p. 105-26, jan./jun. 2015.

\section{Sites consultados:}

www.brasil.gov.br www.oeco.org.br www.pib.socioambiental.org www.capes.gov.br 


\section{Sobre a autora:}

Inês Caroline Reichert: Doutora em Diversidade Cultural e Inclusão Social, trabaIha acerca das questões que envolvem povos indígenas e processos de autoria. Professora de História, História Indígena, Pré-história e Arqueologia e Educação na Universidade Feevale, Novo Hamburgo, RS. E-mail: inesrei@feevale.br

Recebido em 30 de junho de 2018

Aprovado para publicação em 6 de novembro de 2018 